University of Michigan Law School

University of Michigan Law School Scholarship Repository

1920

\title{
Public Utilities-Franchise Rates as Affected by the World War
}

Edwin C. Goddard

University of Michigan Law School

Available at: https://repository.law.umich.edu/articles/1449

Follow this and additional works at: https://repository.law.umich.edu/articles

Part of the Business Organizations Law Commons, Energy and Utilities Law Commons, and the State and Local Government Law Commons

\section{Recommended Citation}

Goddard, Edwin C. "Public Utilities-Franchise Rates as Affected by the World War." Mich. L. Rev. 18 (1920): 320-4.

This Response or Comment is brought to you for free and open access by the Faculty Scholarship at University of Michigan Law School Scholarship Repository. It has been accepted for inclusion in Articles by an authorized administrator of University of Michigan Law School Scholarship Repository. For more information, please contact mlaw.repository@umich.edu. 
Public Uthlitres-Franchise Rates as Affected by the World WarThe economic convulsions due to the World War are abundantly reflected in the relations between the public and their public utilities operating under franchises fixing rates for service. The enormous rise in cost of labor and materials has, in many cases, so reduced the net income of such utilities as to make it a negative quantity at existing franchise rates. The utilities are crying to be saved from bankruptcy, but the unfortunate suspicion bred by past dealings of many such companies has made the public skeptical, and perhaps in many cases entirely unreasonable. In some cases plain selfishness may explain the attitude on both sides. The Supreme Court of the United States has recently held that a contract is still a contract, notwithstanding the critical conditions caused by the war. Columbus $R y . P$. \& $L$. Co. v. Columbus, (U. S. 1919) 39 Sup. Ct. 349, (see 17 Mrcz. L. REv. 689), followed in Michigan Ry. Co. v. Lansing, (1919) 260 Fed. 322 . Though the German steamship company may have been justified in turnitg back and failing to carry out its contract to deliver at Plymouth and Cherbourg gold shipped on the Kronprinzessin Cecilie, since the imminent danger of capture by 2 belligerent which would have ended possibility of performance excused 
performance entirely, Kronprinzessin Cecilie, 244 U. S. 13, yet this does not affect the general principle "that if a party charge himself with an obligation pussible to be performed the must abde by it. unless performance is rendered impossible by the act of God, the law, or the other party. Unforeseen diffculties will not excuse performance." $I b$. The very essence of a contract is that the contractor takes the risk within the limits of his undertaking. Day v. U. S., 245 U. S. 159; North Heinpstead v. Pub. Serv. Corp., 176 N. Y. S. 621. The courts cannot relieve nor make new contracts for the parties. Muscatine Lighting Co. v. Muscatine, (Ig19) 256 Fed. 928.

In the Columbus case the terms of the franchise were clear, the fare to be charged was explicitly stated, there was no room for interpretation. Though the War Labor Board had granted a fifty per cent increase in wages to the employees of the company, yet this was not an intervention by the government as in Metropolitan Water Board v. Dick, Kerr \& Co., [1918] A. C. II9. A rise in the cost of labor is one of the risks. Indeed it is not shown that the franchise would be unprofitable for the whole 25 years period. Would it make a difference if it were shown? The company, then, could not throw up its franchise and ask the aid of a court of equity to relieve it from its hard bargain. The city, acting under state authiority, had made the contract and was bound by it. Vicksburg v. Vicksburg Waterworks Co., 206 U. S. 496. Can it be supposed that the company would have revised the bargain in favor of the city if the advantages had been reversed? The company must be held equally bound though temporarily at least, the operation of the lines must result in a loss. The remedy, if any be needed, addresses itself to the duly constituted authorities. See also Moorhead v. Union $L$. $H$. \& P. Co., (1918) 255 Fed. 920; Hillsdale Gaslight Co. v. Hillsdale, (rg19) 258 Fed. 485.

During 1919 many rate disputes growing out of this high operating cost have come to the cour is of last resort. Some may be noted which involve contracts between the utility and the municipality which granted the franchise to operate. In 17 MrCr. L. REv. 420 attention was called to the unpleasant surprise the public was having in discovering that franchise rates which had been upheld as fixed and binding against the public when in favor of the utilities, were no longer fixed, but subject to revision upward now that they were unprofitable and ruinous to the utilities. The utilities have cried for relief to the public utilities commissions, the people's own boards, and their cry is being heard, for experience shows that such commissions are much more likely than the local authorities to grant at least emergency relief. State v. Lewis, (Ind., 1918) 120 N. E. 129; Ottumwa Ry. \& Light Co. v. Ottumzwa, (Ia.,'1919) 173 N. W. 270.

That a franchise between a municipality acting within its powers and a utility corporation is a binding contract is still undoubted, law, North Hempstead v. Pub. Serv. Corp. 176 N. Y. S. 621; Cleveland v. Cleveland City $R y$. Co., 194 U. S. 517 ; Interurban Ry. Co. v. Pub. Utilities Com., (Ohio, 1918) 120 N. E. 83I ; Muscatine Lighting Co. v. Muscatine, (1919) 256 Fed. 929; Hillsdale Gaslight Co. v. Hillsdale, (1919) 258 Fed. 485 , but it is be- 
coming much clearer how often the city in assuming to fix rates has acted without proper legislative authorization, Ottumwa $R y$. \& Light Co. v. Otzumwa, supra; Georgia Ry. \& Power Co. v. Railroad Com., (Ga., 1919) 98 S. E. 606; Kalamazoa v. Circuit Iudge, (1918) 200 Mich. 146; San Arttonio Public Sero. Co. v. San Antonio, (1919) 257 Fed. 467 ; Atlarita v. Atlanta Gaslight Co., (Ga. 1919) 100 S. E. 439; Winchester v. Winchester Waterworks Co., (U. S. Adv. Ops., Jan. 5, 1920), and that such rates when lawfully fixed are always subject to the police power of the state, which cannot be surrendered, Koehn v. Pub. Serv. Com., (1919) 176 N. Y. S. 147; St. Louis v. Pub. Serv. Co., (Mo., 19I8) 207 S. W. 799; Atlantic Coast Electric Ry. Co. v. Pub. Utilities Com., (N. J., 1918) 104 Atl. 218; Ititerurbar $R y$. Co. v. Pub. Utilities Com., (Ohio, ror8) 120 N. E. 83I; Salt Laike City v. Utah Light \& Traction Co., (Utah, I918) 173 Pac. 556; Georgia Ry. Es Power Co. v. Railroad Com., (Ga., I9I9) $98 \mathrm{~S}$. E 696 , and hence that in all cases except where the people have restrained the legislature in the constitution the rates fixed in the franchise, and which are binding as against the city, may be raised by the legislature, Interurbar $R y$. Co. v. Puo. Utilities Com., supra, or by a public commission to which the legislature has clearly committed such:power. Koehn v. Pub. Serv. Com., (19rg) 176 N. Y. S. 147; State v. Lezeris. (Ind., I018) I20 N. E. 120. This is nothing more than to say that when the state through one of its minor subdivisions has made a binding contract it has the power, with or without the consent of such subdivision, to release the other party to the contract, even though it may be admitted the other party would not release the state if the conditions were reversed. This it does, not out of generosity, but because it regards it as good public policy to have its public utilities in good financial condition so as to insure good service. Just why the locality more immediately affected does not usually take this view of it is a study in psychology or sociology rather than in law. Most of the cases show the cities trying to prevent the commissions from hearing the cry of the utility, or granting relief. Koehn v. Pub. Serv. Co., supra; Atlantic Coast Electric Railway Co. v. Pub. Utility Co., (N. J., I918) I04 Atl. 218; Salt Lake City v. Utah Light \& Traction Co., (Utah, I018) 173 Pac. 556; Georgia Ry. \& Power Co. v. Railroad Com., (Ga., 1919) 98 S. E. 696.

Such was the case of International Ry. Co. v. Pub. Serv. Com., (19rg) 226 IN. Y. 474, which well illustrates how since 1917 the shoe pinches the foot of the other wearer, and the city after putting it on is struggling to kick it off, while the utility after trying to keep out of it is now eager to get in. In 19r6 the city of Buffalo, claiming that the permitted fare was too high, petitioned the Public Service Commission to fix a just and reasonable rate. For two years the petition lay dormant. Then the company, claiming it was no longer a question of lower rates, but a choice between higher rates and bankruptcy, joined the now unwilling city in its forgotten prayer for a revision. The Commission, siding with the city, refused to accept the unwelcome and long delayed answer, but the Court of Appeals found the Commission must hear the case. In Matter of Quinby v. Public Serv. Com., 223 N. Y. 244, the court 
had held that in the absence of clear and definite language it would not be assumed that the legislature had authorized the commission to annul conditions imposed by local authorities, but the conditions in the Buffalo franchise necessarily implied an agreement for revisions. The New York con. stitution, like that of many other states, e. g., Missouri, St. Louis v. Pub. Serv. Com., 207 S. W. 799; and Utah, Salt Lake City v. Utah Light and Traction Co., I73 Pac. 556, forbids the construction or operation of a street railroad without the consent of the local authorities first obtained. This means the consent may be conditioned on charging a named rate of fare, but it does not remove beyond the control of the legislature in the exercise of its police power a revision of the rate so agreed upon. People ex rel. Glen Falls v. Pub. Serv. Com., 225 N. Y. 216. Whether the municipality might revoke its consent if the legislature should raise the rate was left open in that case, and again in the recent case of International Ry. Co. v. Pub. Serv. Com., $226 \mathrm{~N}$. Y. 474, but apparently the New York Legislature has given to the Commission all the power it had over rates not already fixed by statute, Niagara Falls v. Pub. Serv. Com., I77 N. Y. S. 86r (Sept.; 19ro), or by legislative sanction equivalent to a statute, Quinby v. Pub. Serv. Com., 223 N. Y. 244; Koehn v. $P$ ub. Sero. Com., 176 N. Y. S. 147 . In those cases even though the statutory rate might be confiseatory the Commission is not endowed with power to so adjudge. They are outside its jurisdiction. People ex rel. Gas Co. of

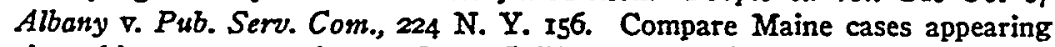
since this note was written: In re Guilford Water Co's. Rates, 108 Atl. 446; In re Searsport Water Co., Ibid. 452; In re Island Falls Water Co., Ibid. 459.

There is no longer any doubt that in general as against the municipality reasonable rates fixed by contract between the municipality and the utility are liable to be superceded by rates fixed by the legislature in the exercise of its police power, or by a commission under legislative authority clearly conferred. Union Drv Goods Co. v. Georgia Pub. Serv. Corp., 248 U. S. 372 (1919). From this it often results that franchise rates cannot be changed as against the utility, because it would amount to impairing the obligation of a contract, but they may be changed by the legislature as against the municipality because the municipality is a subordinate division of the state and is always subject to the legislative power, except as restrained by the constitution. Interurban Ry. Co. v. Pub. Utilities Com., (Ohio, I9I8) 120 N. E. 83I; Salt Lake City v. Utah Light \& Traction Co., (Utah, 1918) 173 Pac. 5.56; Englewood v. Denver \& So. Platt Ry. Co., 248 U. S. 294 (rgrg), followed in Black v. New Orleans Ry. \& Light Co., (La., 1919) 82 So. 81, refusing remedy in such a case to a citizen taxpayer; State v. Lewis, (Ind., 1918) 120 N. E. 129. But certainly if the statutes leave with the municipalities the power to fix rates they may enter into mutually binding contracts with refer. ence thereto, and a recent case holds that when such a contract is once entered into the city as well as the company is protected against a change even by the legislature by reason of the Federal Constitutional prohibition against any state passing a law impairing the obligation of a contract. Cincinati v. Pub. Utility Com. (Ohio, 1918) 12I N. E. 688. As to the municipality this may be doubted, and Jones, J., in dissenting points out that municipalities 
are political subdivisions of the state, and mere agents subject to the power of the state to change its regulations. It would seem that only a constitutional provision could restrain the legislature. State v. Lewis, (Ind., 1918) I20 N. E. I29; Westinghouse Electrical \& Mfg. Co. v. Binghampton Ry. Co., (1919) 255 Fed. 378, 408. In such case it gets its power, not from the legislature, but from the people and the municipality is then, of course, beyond the reach of the legislature. Interurban Ry. Co. v. Pub. Utilities Com., (Ohio, 1918) 120 N. E. 831 .

What utilities will do that find themselves headed for bankruptcy and denied increase over franchise rates does not fully appear. They may try coercion by refusal to operate, as in Toledo and some other places, but so far as the courts are concerned it seems clear they cannot grant relief, even by establishing a receivership. The receiver must operate under the contract. Westinghouse Electrical \& $M f g$. Co. v. Binghampton Ry. Co., supra. North American Construction Co. v. Des Moines City Ry. Co., (1919) 256 Fed. 107, in which the court suggests that if it is a question of a raise in rates or of a poorer service the class of service must yield rather than the rates. But what right can there be to yield either? It may be bad public policy to insist on such hard bargains against public utilities, but.public policy addresses itself to the legislatures, not to the courts. Muscatine Light Co. v. Muscatine, (1919) 256 Fed. 929. Ottumzera Ry. \& Light Co. v. Ottumzwa. (Ia., I919) 173 N. W. 27o. See also Pub. Utilities Com. v. Rhode Island Co., (R. I., Igrg) 107 Atl. 871, 108 Atl. 66, Michigan Ry. Co. v. Lansing, (1919) 260 Fed. 322. Both the utilities and the public should learn that their interests are largely mutual, and that it may be neither just nor safe to insist on taking all the advantages of a hard bargain. No one can tell when conditions may reverse advantages.

E. C. G. 